\title{
Reduction of sodium content in pork coppa: physicochemical, microbiological and
} sensory evaluation

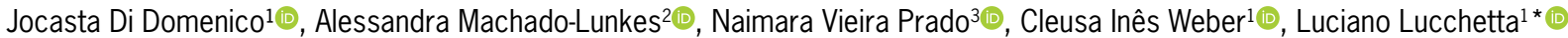

'Universidade Tecnológica Federal do Paraná - Depto. de Ciências Agrárias, C.P. 135 - 85601-971 - Francisco Beltrão, PR - Brasil.

2Universidade Tecnológica Federal do Paraná - Depto. de Química, Bioquímica e Biologia - Francisco Beltrão, PR Brasil.

${ }^{3}$ Universidade Tecnológica Federal do Paraná - Depto. de Física, Estatística e Matemática. - Francisco Beltrão, PR Brasil.

*Corresponding author <lucchetta@utfpr.edu.br>

Edited by: Pedro Esteves Duarte Augusto

Received March 23, 2020

Accepted June 03, 2020
ABSTRACT: Sodium reduction and the substitution of sodium chloride by other salts have been extensively studied in order to produce healthier foods. Coppa is a pork cured product that receives high levels of sodium through the salting process. The objective of this work was to evaluate the impact of reductions in Sodium Chloride ( $\mathrm{NaCl}$ ), substitution by Potassium Chloride $(\mathrm{KCl})$ and reductions in the re-salting time on the physicochemical, microbiological and sensorial characteristics in pork coppa. Four treatments were applied: $\mathrm{T} 1$ with 2 days of salting, 2 days of re-salting and $35 \%$ reduction of $\mathrm{NaCl} ; \mathrm{T} 2$ with 2 days of salting and 3 days of re-salting and $35 \%$ reduction of $\mathrm{NaCl}$; $\mathrm{T} 3$ with 2 days of salting and 2 days of re-salting and replacing $35 \%$ of $\mathrm{NaCl}$ by KCl; $\mathrm{T} 4$ with 2 days of salting and 3 days of re-salting and $35 \%$ replacing $\mathrm{NaCl}$ by $\mathrm{KCl}$. Control: standard treatment was applied with $100 \%$ of $\mathrm{NaCL}$ and salting time was 2 days and then 5 days to re-salting. The reduction in sodium content in processed pork Coppa produced no microbiological nor physicochemical changes. The reduction in salting together with salting and re-salting time and the partial replacement of $\mathrm{NaCl}$ by $\mathrm{KCl}$ resulted in reductions from 2,000 $\mathrm{mg}$ to $1,600 \mathrm{mg}$ of sodium. Sensory evaluation demonstrated that the reduction in re-salting time was efficient using the ideal profile method which showed that treatments $\mathrm{T} 1$ and $\mathrm{T} 2$ were efficient in creating a product that meets consumer expectations.

Keywords: $\mathrm{NaCl}$ replacement, Potassium Chloride, sodium reduction, sensory analysis

\section{Introduction}

The development of chronic diseases, such as hypertension, is associated with sodium consumption that exceeds the levels recommended by the World Health Organization. The estimated average consumption of the Brazilian population is approximately 5-12 g sodium per day, while recommended levels are $2 \mathrm{~g} \mathrm{~d}^{-1}$ (WHO, 2016).

Processed meats contribute to the sodium consumed in our diet. The correlation between excessive intake of sodium chloride $(\mathrm{NaCl})$ and chronic diseases is stimulating the development of products with reduced levels of sodium by the global food industry (Inguglia et al., 2017). In the Brazilian market, $70 \%$ of pork consumption is based on processed products (salami, ham, sausages, mortadella). In 2016, total pork consumption was $14.4 \mathrm{~kg}$ per person, of which processed products account for $10 \mathrm{~kg}$ per inhabitant (Andrade et al., 2018). In general, cured meat products contain a high content of salt $(\mathrm{NaCl})$, approximately $4.5 \%$ (Andrade et al., 2018).

Coppa is a product that is cured, matured and smoked obtained from the pig's shoulder and receives high levels of sodium in its formulation through the salting and re-salting process steps. Thus, $\mathrm{NaCl}$ has an important function in coppa preservation, namely, the reduction in water content and increase in osmotic pressure resulting in an unfavorable effect on microorganism growth. Furthermore, $\mathrm{NaCl}$ is essential for flavor, texture, stability and maintenance of the quality and safety of cured meats (Doyle and Glass, 2010).
However, a simple reduction in sodium chloride represents a great challenge for food producers, especially in the cured meat production industry. Sodium chloride reduction may result in losses in the typical characteristics of those products, such as shelf -life reduction and a loss of consumer acceptance (Inguglia et al., 2017). Additives such as potassium chloride provide similar salt taste effects and conservation conditions. Although it is often used as a substitute for sodium chloride in reduced sodium food products, the main replacement problem is the occurrence of a bitter taste in the product (Parpia et al., 2018).

Sensory analysis in food is an important approach to obtaining information about consumer perception. The ideal profile method is a descriptive method, widely used for product development and optimization. This method also allows for identifying the sensory characteristics of a product considered important to consumers (Worch and Punter, 2015). This study evaluated sodium reduction in cured pork coppa replacing sodium chloride by potassium chloride which reduces the re-salting step time.

\section{Materials and Methods}

The experiment was carried out in a Brazilian pork products factory located in the west of the state of Santa Catarina, which operates under the Federal Inspection System. The physicochemical and microbiological analyses were conducted in the company's laboratories. 
The coppas were made with intact shoulder cuts $(0.900$ to $1.400 \mathrm{~kg}$ ) of slaughtered pigs with an average age of 160 days. The spices and aroma, flavor and conservation condiments added were $9.50 \%$ up to the shoulder cut weight which consisted of: salt $(\mathrm{NaCl}$ - $7.5 \%)$, sugar $(0.85 \%)$, mix of clove, cinnamon, black pepper, flavor enhancers $(0.55 \%)$, nitrite and nitrate $(0.25 \%)$, ascorbic acid $(0.25 \%)$ and natamycin $(0.10 \%)$. The $\mathrm{KCl}$ was replaced at a specified percentage of $\mathrm{NaCl}$.

To produce the coppa, the pork shoulders were subjected to the salting and re-salting process, when the pieces were massaged uniformly in a mixture of sodium chloride and condiments. The standard salting time was 2 days and 5 days to re-salting. This protocol was known as the standard treatment. To define the ideal product, changes were made in the coppa salting process in current use in the industry, adopting the following techniques: direct salt reduction, replacement of $\mathrm{NaCl}$ by $\mathrm{KCl}$ and reduction in re-salting time (Table 1).

After the salting process, the product was washed to remove condiments and spices in a chiller adapted for this purpose, maintained at a temperature between 35 and $40{ }^{\circ} \mathrm{C}$ for $45 \mathrm{~min}$. Next, the shoulder cuts were placed in a collagen casing and subjected to the smoking process for $30 \mathrm{~h}$. After the smoking phase, the products were maintained for 30 days in maturation rooms with relative humidity between $60 \%$ and $80 \%$ and at a temperature between 18 and $20{ }^{\circ} \mathrm{C}$ allowed to gradually decrease down to $12{ }^{\circ} \mathrm{C}$. Finally, the collagen casing was removed and the coppas vacuum-packed in polyethylene packages.

The sodium content and lipid oxidation analysis were performed shortly after the maturation period. The analyses of humidity, lipids, proteins, nitrite, nitrate, $\mathrm{pH}$, water activity (Aw) and color were carried out in triplicate after a 30 day maturation process at 0,30 , 60 and 90 days of storage. All analyses were carried out in laboratories qualified by Brazilian regulatory and supervisory agencies and followed the methods described in the official methods of the AOAC (2005). The physicochemical and sensorial analyses were

Table 1 - Treatments used to prepare pork coppa with reduced sodium content.

\begin{tabular}{|c|c|c|c|}
\hline \multicolumn{4}{|c|}{ Formulations ${ }^{\text {a }}$ Salting/Re-salting ** Total Salt Replacement of $\mathrm{NaCl}$ by $\mathrm{KCl}$} \\
\hline & days & 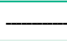 & - \\
\hline${ }^{*}$ Standard & 7 & 100 & - \\
\hline $\mathrm{T} 1$ & 4 & 65 & - \\
\hline $\mathrm{T} 2$ & 5 & 65 & - \\
\hline T3 & 4 & 65 & 35 \\
\hline T4 & 5 & 65 & 35 \\
\hline \multicolumn{4}{|c|}{$\begin{array}{l}{ }^{*} \text { Corresponding to the total of salt from de Standard formulation that attain } \\
7.5 \% \text { salt per shoulder cut weight. }{ }^{*} \text { Standard }=100(7.5 \% \mathrm{NaCl}, 7 \text { days } \\
\text { salting/re-salting); T1 = direct reduction of the salting/re-salting time ( } 4 \text { days) } \\
\text { of } 35 \%(65 \% \mathrm{NaCl}) ; \mathrm{T} 2=\text { direct reduction of the salting/re-salting time ( } 5 \\
\text { days) of } 35 \%(65 \% \mathrm{NaCl}) ; \mathrm{T} 3=\text { partial replacement of } \mathrm{NaCl} \text { by } \mathrm{KCl}(65 \%+ \\
35 \%, 4 \text { days salting/re-salting); T4 = partial replacement of } \mathrm{NaCl} \text { by KCl }(65 \% \\
+35 \%, 5 \text { days salting/re-salting). }\end{array}$} \\
\hline
\end{tabular}

performed after the 30 day maturation process. The shelf life of coppa is 90 days after maturation.

\section{Sodium analysis}

One g of coppa was triturated and homogenized, after being digested in a reactor with nitric and perchloric acid. The sodium content was determined by the ICPAES Shimadzu inductively coupled plasma atomic emission spectrophotometer on a wavelength reading of 589-592 $\mathrm{nm}$. Sodium standards (0.1 to $\left.10 \mathrm{mg} \mathrm{kg}^{-1}\right)$ were used for calibration and results were expressed in $\mathrm{mg}$ $100 \mathrm{~g}^{-1}$ of sodium (APHA, 1992).

\section{Lipid oxidation analysis}

To verify the oxidation degree the test of reactive substances to 2-thiobarbituric acid (TBARs) by distillation was used. The TBARS value was estimated using a double beam UV-VIS spectrophotometer on a wavelength of 532 $\mathrm{nm}$. The results were expressed in milligrams of MDA (malondialdehyde) $\mathrm{kg}^{-1}$ (Koniecko, 1985).

\section{Chemical composition analysis}

Moisture content was determined in accordance with the gravimetric method using a drying oven at $105{ }^{\circ} \mathrm{C}$. The lipid content was determined by Soxhlet extraction. Total nitrogen was determined in accordance with the Kjeldahl method with a conversion factor of 6.25 for protein content. The nitrate and nitrite contents were determined by a spectrophotometer at $540 \mathrm{~nm}$. The nitrate was converted into nitrite by a reduction in the spongy cadmium column. All nitrite was quantified by the Griess-Ilosvay reaction. The $\mathrm{pH}$ was measured using a digital potentiometer and Aw was analyzed by direct reading in accordance with the primary method for dew point. All methods were described in the official methods of the AOAC (2005).

\section{Color analysis}

To measure color a colorimeter was used, and eight replicates were analyzed for each treatment. The evaluated parameters were expressed in: $\mathrm{L}^{*}$ (luminosity), and intensity; - $\mathrm{a}^{*}$ (green) and $+\mathrm{a}^{*}(\mathrm{red}) ;-\mathrm{b}^{*}$ (blue) and $+b^{*}$ (yellow).

\section{Microbiological analysis}

Thermotolerant coliforms, coagulase-positive Staphylococcus, Salmonella sp. and Listeria monocytogenes were analyzed in accordance with methods described by APHA (APHA, 1992).

\section{Sensory analysis}

The ideal profile method was the sensory method applied in order to verify which treatment is closer to the consumer's desired product. It was carried out at the city of Francisco Beltrão, Paraná - Brazil, with the participation of 100 untrained panelists. The sensory test applied was the ideal profile method (Varela and Ares, 2014). Coppas were cut into $1.5 \mathrm{~mm}$ thick slices. The 
samples on disposable plates were randomly assigned to each panelist with three-digit numbers, in sequential, monomodal form, in order to evaluate the samples in terms of color intensity, odor, salty taste, texture and bitterness. The sensorial evaluation was performed after the maturation process (time 0 day). This study was approved by the Research Ethics Committee of the Federal University of Technology - Paraná - UTFPR (Approval No. 12,597,513.0.0000.5547).

\section{Statistical analysis}

The microbiological, and physicochemical data were analyzed by variance analysis (ANOVA) followed by Tukey's test, considering $p<0.05$ to be statistically significant. The sensorial analysis data were analyzed to verify the correlation between the samples and the sensory attributes. The result of the ideal profile method was analyzed using Principal Component Analysis (PCA) and Hierarchical Cluster Analysis (HCA). The Statistica Advanced Quality Control software program v.12.0 was used.

\section{Results}

The reduction in salting and re-salting time from 7 to 4 days and the $\mathrm{NaCl}$ replacement by $\mathrm{KCl}$ provided a significant reduction in sodium in this meat product (Table 2). The salting and re-salting time reduction and the amount of $\mathrm{NaCl}$ in the process did not result in a reduction in sodium concentration at $\mathrm{T} 2$ compared to the standard treatment. The $\mathrm{T} 1$ and $\mathrm{T} 3$ treatments presented the lowest concentration of sodium and the difference between them was not significant (Table 2). It was observed that, in general, the exposure time of coppa to salt has great influence on the concentration of sodium in the product.

The lipid oxidation measured by TBARS values were evaluated at time 0 (30 days of maturation process), and the highest value found was $0.23 \mathrm{mg}$ malondialdehyde $\mathrm{kg}^{-1}$ for the standard treatment.

All the treatments stored over the 90 day of shelf life met the current legislation for the physicochemical parameters including lipid, protein, nitrite and nitrate contents and safety consumption. Despite the variation in

Table 2 - Sodium content and lipid oxidation after 30 days of coppa maturation process.

\begin{tabular}{lcc}
\hline Treatment & \multicolumn{1}{c}{ Sodium } & \multicolumn{1}{c}{ TBARS } \\
\hline & $\mathrm{mg} \mathrm{kg}^{-1}$ & $\mathrm{mg} \mathrm{of} \mathrm{MDA} \mathrm{kg}{ }^{-1}$ \\
Standard & $2833.14 \pm 259.01^{\mathrm{a}}$ & $0.23 \pm 0.01^{\mathrm{a}}$ \\
T1 & $1771.67 \pm 297.98^{\mathrm{b}}$ & $0.08 \pm 0.0^{\text {cd }}$ \\
T2 & $2971.09 \pm 103.39^{\mathrm{a}}$ & $0.10 \pm 0.0^{\mathrm{c}}$ \\
T3 & $1683.83 \pm 94.92^{\mathrm{b}}$ & $0.15 \pm 0.02^{\mathrm{b}}$ \\
T4 & $1950.19 \pm 20.28^{\mathrm{b}}$ & $0.07 \pm 0.01^{\mathrm{d}}$ \\
\hline
\end{tabular}

Standard $=(\mathrm{NaCl} 100 \%+7$ days salting $) ; \mathrm{T} 1=(\mathrm{NaCl} 65 \%+4$ days salting $) ;$ $\mathrm{T} 2=(\mathrm{NaCl} 65 \%+5$ days salting $) ; \mathrm{T} 3=(65 \% \mathrm{NaCl}+35 \% \mathrm{KCl}+4$ days salting); $\mathrm{T} 4=(65 \% \mathrm{NaCl}+35 \% \mathrm{KCl}+5$ days salting). Mean rates $(n=3)$ followed by their standard deviation. Means followed by the same small letter in the same column do not statistically differ at $5 \%$ probability by Tukey test $(p<0.05) . M D A=$ malonaldehyde. humidity indexes during the 90-day storage period, in all time periods evaluated, every treatment met the moisture content recommended by Brazilian legislation (Table 3).

The values of $\mathrm{pH}$ and Aw are presented in Table 4. For $\mathrm{pH}$, standard treatment, $\mathrm{T} 3$ and $\mathrm{T} 4$ did not present any significant difference $(p<0.05)$ during the storage period. There was no significant difference $(p<0.05)$ between treatments at 30 and 90 storage days. Aw values showed significant differences $(p<0.05)$ between treatments and at all times evaluated. Aw ranged from 0.78 to 0.86 . Thus, all treatments are in accordance with the legislation parameters (MAPA, 2000).

The results of the thermotolerant coliform, coagulase-positive Staphylococcus, Salmonella sp. and Listeria monocytogenes analyses from all treatments were within the limits established by Brazilian legislation (ANVISA, 2001).

The color analysis was carried out by the CIElab system, using the coordinates $\mathrm{L}^{*}$ (luminosity), $\mathrm{a}^{*}$ (intensity of red/green) and $b^{*}$ (intensity of yellow and blue). A significant difference for coordinate $a^{*}$ was observed $(p<0.05)$ in the treatments, except at 60-day storage. The $\mathrm{T} 2$ treatment did not present any difference during the 90-day storage period. Between the run times for each treatment, there was also an increase in this parameter for the standard treatment and $\mathrm{T} 1$, while $\mathrm{T} 2$, T3 and T4 reduced over time (Table 5).

There were no significant differences between the standard and the T3 treatments $(p<0.05)$ for coordinate $\mathrm{b}^{*}$ and none either $(p<0.05)$ between the treatments at 30-day and 60-day storage time. The $\mathrm{L}^{*}$ parameter did not show any significant difference $(p<0.05)$ from one treatment to the next, except for T2 which presented variation after 90-day storage.

To obtain a coppa formulation that meets consumer expectations and maintains food safety, the ideal profile method was applied. The results of sensory analysis were enhanced by multivariate analysis (hierarchical method) and were obtained from the evaluations of 100 untrained panelists as shown in Figures 1 and 2.

The principal component analysis demonstrated that components 1 and 2 accounted for $87.79 \%$ of the explained variance. The standard treatment is the one that presented the highest scores for salty taste and the lowest scores for color and odor. On the other hand, the $\mathrm{T} 2$ treatment presented the highest odor and color scores. The standard sample also recorded the lowest scores for bitter taste. The hierarchical method showed that a group was formed between the ideal profile, in which T1 and $\mathrm{T} 2$ stand out, thus indicating a similarity between them (Figure 2).

\section{Discussion}

\section{Physicochemical parameters}

Studies of $\mathrm{NaCl}$ replacement by $\mathrm{KCl}$ had satisfactory results in terms of sodium reduction in meat products. A study carried out on bacon whose treatments 
Table 3 - Proximal composition and concentration of nitrate and nitrite in periods 0, 30, 60 deand 90 days of coppa storage.

\begin{tabular}{|c|c|c|c|c|c|c|}
\hline Period (days) & Standard & $\mathrm{T} 1$ & $\mathrm{~T} 2$ & T3 & T4 & Reference value \\
\hline \multicolumn{6}{|c|}{ Humidity (\%) } & \multirow{5}{*}{$\leq 40 \%$} \\
\hline 0 & $39.76 \pm 0.46^{\mathrm{bB}}$ & $39.40 \pm 1.00^{\mathrm{aB}}$ & $40.41 \pm 1.20^{\mathrm{aAB}}$ & $40.44 \pm 0.99 \mathrm{bAB}$ & $43.32 \pm 1.90^{\mathrm{aA}}$ & \\
\hline 30 & $42.74 \pm 0.92^{\mathrm{aA}}$ & $38.85 \pm 0.23^{\mathrm{aBC}}$ & $37.05 \pm 0.05^{\mathrm{bD}}$ & $39.01 \pm 0.99^{\mathrm{bB}}$ & $37.27 \pm 0.10^{\mathrm{cd} C}$ & \\
\hline 60 & $39.58 \pm 0.19^{\mathrm{bA}}$ & $34.98 \pm 0.19 b c$ & $32.56 \pm 0.49^{c D}$ & $38.92 \pm 0.20^{\mathrm{bA}}$ & $37.93 \pm 0.38^{\mathrm{bcB}}$ & \\
\hline 90 & $39.10 \pm 0.18^{\mathrm{bBC}}$ & $38.26 \pm 0.73^{a c}$ & $39.67 \pm 0.24^{\mathrm{aB}}$ & $42.48 \pm 0.17^{\mathrm{aA}}$ & $40.20 \pm 0.59^{\mathrm{bB}}$ & \\
\hline \multicolumn{6}{|c|}{ Lipid (\%) } & \multirow{5}{*}{$\leq 35 \%$} \\
\hline 0 & $20.88 \pm 0.10^{\mathrm{aB}}$ & $22.78 \pm 0.20^{\mathrm{bA}}$ & $20.46 \pm 0.16^{c B}$ & $20.42 \pm 0.10^{\mathrm{bB}}$ & $15.37 \pm 0.40^{d C}$ & \\
\hline 30 & $15.49 \pm 0.10^{\mathrm{dE}}$ & $27.65 \pm 0.10^{a A}$ & $22.12 \pm 0.12^{\mathrm{bD}}$ & $24.48 \pm 0.10^{a c}$ & $26.65 \pm 0.08^{a \mathrm{~B}}$ & \\
\hline 60 & $20.02 \pm 0.24^{b c}$ & $22.84 \pm 0.38^{\mathrm{bB}}$ & $30.92 \pm 0.70^{a A}$ & $21.21 \pm 1.16^{\mathrm{bBC}}$ & $22.33 \pm 0.58^{\mathrm{bB}}$ & \\
\hline 90 & $17.18 \pm 0.45^{\mathrm{CAB}}$ & $18.31 \pm 0.80^{c A}$ & $17.12 \pm 0.48^{\mathrm{dAB}}$ & $15.47 \pm 0.41^{\mathrm{cB}}$ & $17.92 \pm 1.16^{\mathrm{cA}}$ & \\
\hline \multicolumn{6}{|c|}{ Nitrate $\left(\mathrm{mg} \mathrm{kg}^{-1}\right)$} & \multirow{5}{*}{$\leq 150$} \\
\hline 0 & $18.63 \pm 0.20^{\mathrm{aA}}$ & $0.10 \pm 0.00^{\mathrm{dE}}$ & $4.40 \pm 0.4^{\mathrm{bc}}$ & $2.35 \pm 0.15^{\mathrm{aD}}$ & $7.24 \pm 0.25^{\mathrm{cB}}$ & \\
\hline 30 & $0.10 \pm 0.00^{\mathrm{cB}}$ & $11.31 \pm 0.10^{\mathrm{aA}}$ & $0.10 \pm 0.00^{\mathrm{CB}}$ & $0.10 \pm 0.00^{\mathrm{bB}}$ & $0.10 \pm 0.00^{\mathrm{cB}}$ & \\
\hline 60 & $0.10 \pm 0.00^{\mathrm{cB}}$ & $2.57 \pm 0.58^{\mathrm{bB}}$ & $8.05 \pm 2.69^{a A}$ & $0.88 \pm 1.36^{\mathrm{abB}}$ & $0.10 \pm 0.00^{c B}$ & \\
\hline \multirow[t]{2}{*}{90} & $14.85 \pm 2.70^{\mathrm{bA}}$ & $0.29 \pm 0.13^{\mathrm{cB}}$ & $4.89 \pm 6.71^{\mathrm{bB}}$ & $0.00 \pm 0.00^{\mathrm{bB}}$ & $1.78 \pm 0.89^{\mathrm{bB}}$ & \\
\hline & & & Nitrite $\left(\mathrm{mg} \mathrm{kg}^{-1}\right)$ & & & \multirow{5}{*}{$\leq 150$} \\
\hline 0 & $8.81 \pm 0.3^{\mathrm{aA}}$ & $1.80 \pm 0.20^{\mathrm{aE}}$ & $3.76 \pm 0.10^{\mathrm{aB}}$ & $2.10 \pm 0.10^{\mathrm{aD}}$ & $3.35 \pm 0.14^{\mathrm{cA}}$ & \\
\hline 30 & $2.39 \pm 0.16^{\mathrm{bB}}$ & $1.84 \pm 0.10^{a c}$ & $3.31 \pm 0.10^{\mathrm{aA}}$ & $1.70 \pm 0.20^{\mathrm{acc}}$ & $1.22 \pm 0.07 \mathrm{cD}$ & \\
\hline 60 & $0.96 \pm 0.60^{c A}$ & $0.75 \pm 0.17 b^{A B}$ & $2.12 \pm 0.51^{\mathrm{bA}}$ & $0.95 \pm 0.45^{\mathrm{abA}}$ & $2.03 \pm 0.09 \mathrm{bA}$ & \\
\hline 90 & $4.63 \pm 0.72^{\mathrm{dA}}$ & $2.26 \pm 0.50^{\mathrm{aB}}$ & $1.61 \pm 0.65^{\mathrm{bB}}$ & $1.77 \pm 0.29 \mathrm{aB}$ & $2.53 \pm 0.56^{\mathrm{bB}}$ & \\
\hline
\end{tabular}

Standard $=(\mathrm{NaCl} 100 \%+7$ days salting $) ; \mathrm{T} 1=(\mathrm{NaCl} 65 \%+4$ days salting $) ; \mathrm{T} 2=(\mathrm{NaCl} 65 \%+5$ days salting $) ; \mathrm{T} 3=(65 \% \mathrm{NaCl}+35 \% \mathrm{KCl}+4$ days salting $) ; \mathrm{T} 4$ $=(65 \% \mathrm{NaCl}+35 \% \mathrm{KCl}+5$ days salting). Mean rates $(\mathrm{n}=3)$ followed by their standard deviation. Means followed by the same small letter in the same column do not statistically differ at $5 \%$ probability by Tukey test. $(p<0.05)$. Means followed by the same capital letter in the same line do not statistically differ at $5 \%$ probability by Tukey test $(p<0.05)$.

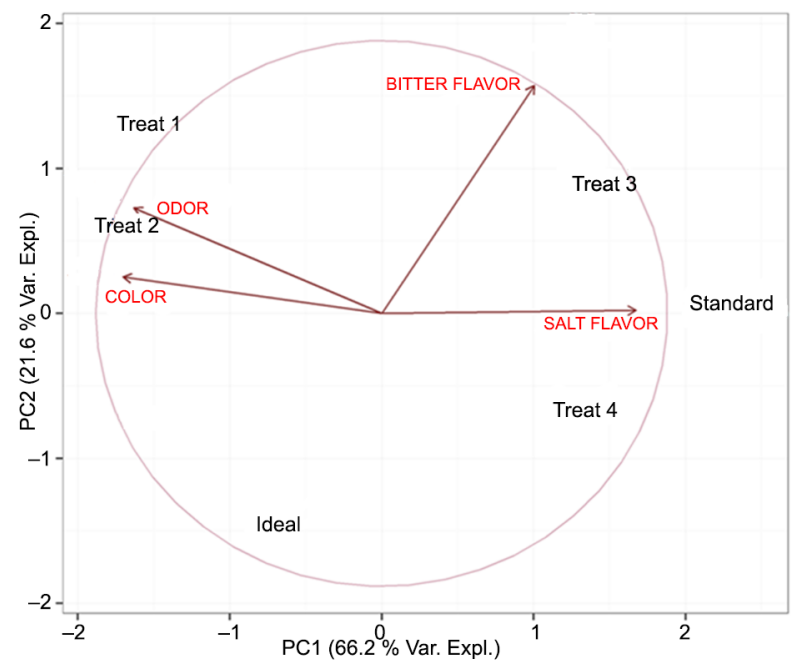

Figure 1 - Principal Component Analysis of coppa sensory characteristics. Var. Expl. = Variance Explaining.

with $40 \%$ of $\mathrm{NaCl}$ replacement by $\mathrm{KCl}$ obtained values of $2,845.82$ and $1,828.07 \mathrm{mg} 100 \mathrm{~g}^{-1}$, respectively, i.e., a reduction of $36 \%$ (Wu et al., 2015). In a study with jerked beef, replacement of up to $50 \%$ of $\mathrm{Nacl}$ by $\mathrm{KCl}$ demonstrated excellent performance, ensuring suitable stability, technological and sensory properties /Vidal et al., 2019). In the same study, the use of calcium chloride resulted in increased bitter taste and rancid flavor. Sodium reduction and its substitution by $\mathrm{KCl} \mathrm{(1:1)} \mathrm{in}$ pork hamburgers obtained a reduction of $49 \%$ in sodium content which in the control treatment was reduced from

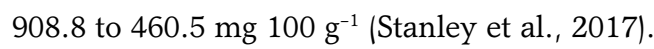

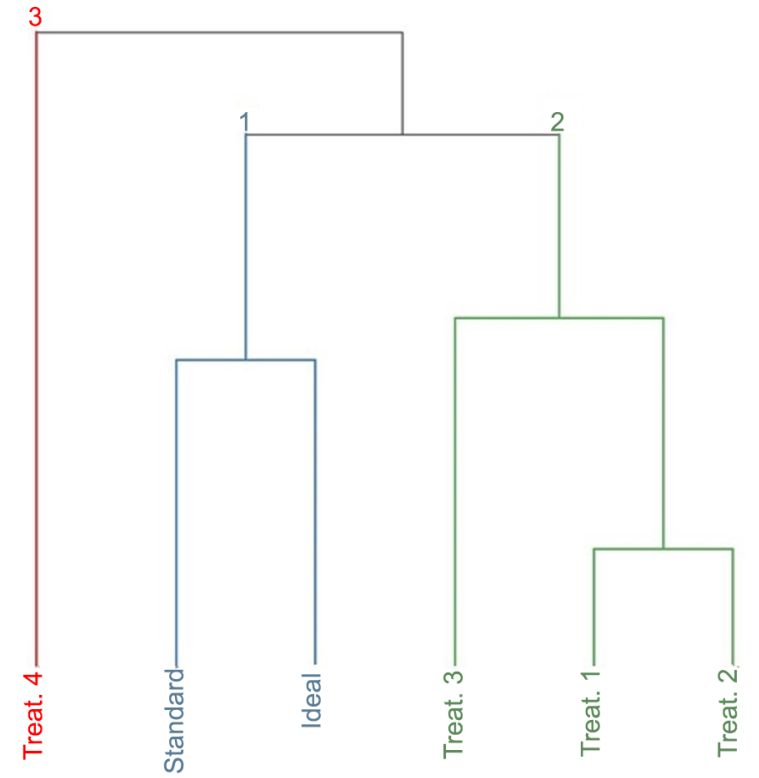

Figure 2 - Hierarchical grouping method of coppa sensory characteristics.

In Tuscan sausage sodium reduction was less expressive. The reduction and partial replacement of $30 \%$ of $\mathrm{NaCl}$ by $\mathrm{KCl}$ resulted in sodium reduction of $14.7 \%$ (Seganfredo et al., 2016). These results agree with our study, which obtained a reduction of $40 \%$ in the sodium content in $\mathrm{T} 3$ and confirm that the percentage of $\mathrm{KCl}$ used directly influences the reduction in sodium content (Table 2). 
Table $4-\mathrm{pH}$, Aw and microbiological analysis in periods $0,30,60$ and 90 days of coppa storage.

\begin{tabular}{|c|c|c|c|c|c|c|}
\hline \multicolumn{7}{|c|}{$\mathrm{pH}$} \\
\hline Period (days) & Standard & $\mathrm{T} 1$ & $\mathrm{~T} 2$ & T3 & T4 & Reference value \\
\hline 0 & $5.54 \pm 0.13^{\mathrm{abB}}$ & $5.53 \pm 0.05^{\mathrm{bB}}$ & $5.48 \pm 0.17^{\mathrm{bB}}$ & $5.73 \pm 0.21^{\mathrm{abBA}}$ & $5.99 \pm 0.2^{\mathrm{aA}}$ & \\
\hline 30 & $5.84 \pm 0.19 \mathrm{aA}$ & $5.97 \pm 0.2^{2 \mathrm{~A}}$ & $6.13 \pm 0.32^{\mathrm{aA}}$ & $6.26 \pm 0.23^{\mathrm{aA}}$ & $6.15 \pm 0.16^{\mathrm{aA}}$ & \\
\hline 60 & $6.11 \pm 0.12^{\mathrm{aAB}}$ & $6.04 \pm 0.14^{\mathrm{aB}}$ & $6.25 \pm 0.01^{\mathrm{aAB}}$ & $6.34 \pm 0.10^{a A}$ & $6.20 \pm 0.02^{\mathrm{aAB}}$ & \\
\hline 90 & $5.88 \pm 0.07^{\mathrm{aA}}$ & $6.09 \pm 0.17^{\mathrm{aA}}$ & $6.14 \pm 0.19^{a A}$ & $6.14 \pm 0.19^{\mathrm{aA}}$ & $6.27 \pm 0.22^{\mathrm{aA}}$ & \\
\hline \multicolumn{6}{|c|}{ Aw } & \multirow{5}{*}{0.90} \\
\hline 0 & $0.81 \pm 0.00^{\mathrm{bD}}$ & $0.85 \pm 0.00^{\mathrm{bAB}}$ & $0.83 \pm 0.00^{\mathrm{bB}}$ & $0.85 \pm 0.00^{\mathrm{aA}}$ & $0.82 \pm 0.00^{c c}$ & \\
\hline 30 & $0.78 \pm 0.00^{\mathrm{bE}}$ & $0.86 \pm 0.00^{\mathrm{aA}}$ & $0.83 \pm 0.00^{\mathrm{bc}}$ & $0.85 \pm 0.00^{\mathrm{aB}}$ & $0.82 \pm 0.00^{\mathrm{bD}}$ & \\
\hline 60 & $0.86 \pm 0.02^{\mathrm{aA}}$ & $0.84 \pm 0.00^{\mathrm{cA}}$ & $0.85 \pm 0.00^{\mathrm{aA}}$ & $0.84 \pm 0.00^{\mathrm{bA}}$ & $0.85 \pm 0.00^{\mathrm{aA}}$ & \\
\hline 90 & $0.80 \pm 0.00^{\mathrm{bc}}$ & $0.85 \pm 0.00^{\mathrm{bA}}$ & $0.85 \pm 0.00^{\mathrm{aA}}$ & $0.85 \pm 0.00^{\mathrm{aA}}$ & $0.82 \pm 0.00^{\mathrm{bB}}$ & \\
\hline \multicolumn{7}{|c|}{ Microbiological analysis } \\
\hline \multicolumn{6}{|c|}{ Thermotolerant coliforms UFC g ${ }^{-1}$} & \\
\hline 0 & $<1.0 \times 10$ & $<1.0 \times 10$ & $<1.0 \times 10$ & $<1.0 \times 10$ & $1.0 \times 10$ & \multirow{4}{*}{$<10^{2}$} \\
\hline 30 & $<1.0 \times 10$ & $<1.0 \times 10$ & $<1.0 \times 10$ & $<1.0 \times 10$ & $1.0 \times 10$ & \\
\hline 60 & $<1.0 \times 10$ & $<1.0 \times 10$ & $<1.0 \times 10$ & $<1.0 \times 10$ & $<1.0 \times 10$ & \\
\hline 90 & $<1.0 \times 10$ & $<1.0 \times 10$ & $<1.0 \times 10$ & $<1.0 \times 10$ & $<1.0 \times 10$ & \\
\hline \multicolumn{6}{|c|}{ Salmonella ssp } & \multirow{5}{*}{ absence in $25 \mathrm{~g}$} \\
\hline 0 & absence & absence & absence & absence & absence & \\
\hline 30 & absence & absence & absence & absence & absence & \\
\hline 60 & absence & absence & absence & absence & absence & \\
\hline 90 & absence & absence & absence & absence & absence & \\
\hline \multicolumn{6}{|c|}{ Listeria monocytogenes } & \multirow{5}{*}{ absence in $25 \mathrm{~g}$} \\
\hline 0 & absence & absence & absence & absence & absence & \\
\hline 30 & absence & absence & absence & absence & absence & \\
\hline 60 & absence & absence & absence & absence & absence & \\
\hline 90 & absence & absence & absence & absence & absence & \\
\hline \multicolumn{6}{|c|}{ Coagulase-positive Staphylococcus UFC g ${ }^{-1}$} & \multirow{5}{*}{$<10^{3}$} \\
\hline 0 & $1.5 \times 10^{2}$ & $1.2 \times 10^{2}$ & $1.0 \times 10^{3}$ & $2.5 \times 10^{2}$ & $1.8 \times 10^{2}$ & \\
\hline 30 & $<1.0 \times 10$ & $<1.0 \times 10$ & $<1.0 \times 10$ & $<1.0 \times 10$ & $<1.0 \times 10$ & \\
\hline 60 & $<1.0 \times 10$ & $<1.0 \times 10$ & $<1.0 \times 10$ & $8.0 \times 10^{2}$ & $<1.0 \times 10$ & \\
\hline 90 & $1.8 \times 10^{2}$ & $2.3 \times 10^{2}$ & $<1.0 \times 10$ & $3.0 \times 10^{2}$ & $1.0 \times 10^{2}$ & \\
\hline
\end{tabular}

Reduction and substitution of $\mathrm{NaCl}$ by other salts also impact the oxidation of dry cured products. The standard treatment showed a higher content of malonaldehyde due to the fact that $\mathrm{NaCl}$ accelerates the reaction catalyzed by the enzyme lipoxidase (Ma et al., 2007). This enzyme is present in the muscle and promotes the acceleration of lipid oxidation development (Souza et al., 2013). All treatments presented lower content of malonaldehyde than the standard treatment. The T4 treatment exhibited $65 \%$ less malondialdehyde content than the standard treatment. However, the treatment with lower sodium content (T3) showed $35 \%$ lower malonaldehyde values than the standard treatment. These results may be caused by the variation in fat content presented by each piece. Lipid oxidation produces a wide variety of oxidation products, with primary peroxidation compounds called hydroperoxides which subsequently form different aldehydes, such as malonaldehyde (MDA), propanal, hexanal, 4-hydroxynonenal (4-HNE) and other F2-isoprostanes such as 8-iso-prostaglandin F2 $\alpha$ (8-iso-PGF2 $\alpha$ ) (Nachtigall et al., 2019).
In all treatments, malonaldehyde levels were considered low because up to $1.59 \mathrm{mg} \mathrm{kg} \mathrm{mg} 100 \mathrm{~g}^{-1}$ of malonaldehyde does not harm human health and is barely perceived by sensory analysis (Terra et al., 2013).

Studies have evaluated the effect of a $50 \% \mathrm{NaCl}$ reduction and its replacement by $\mathrm{KCl}$ on the lipid oxidation of fermented cured sausages and observed reduction in the intensity of lipid oxidation reactions (Santos et al., 2017). In pork hamburger, the authors did not notice a significant difference during the storage period (Staley, Bower and Sulivan, 2017).

The increase in oxidation may be the result of $\mathrm{NaCl}$ acting as a pro-oxidant, displacing the iron ions with sodium in the heme pigments of muscle tissue, while others recognize the chloride ion acting on the lipid. Lipid oxidation is increased by increasing the ionic strength (Terra et al., 2013).

The maximum moisture content allowed by legislation for coppa is $40 \%$. Thus, only treatment 1 met the legislative requirements at all storage times evaluated (Table 3). In cured loin the formulation containing $100 \%$ 
Table 5 - Color analysis in periods 0, 30, 60 and 90 days of coppa storage.

\begin{tabular}{|c|c|c|c|c|c|}
\hline \multicolumn{6}{|c|}{$a^{*}$} \\
\hline Period (days) & Standard & T1 & $\mathrm{T} 2$ & T3 & T4 \\
\hline 0 & $9.22 \pm 0.36^{c D}$ & $9.89 \pm 0.89^{\mathrm{CCD}}$ & $13.33 \pm 3.81^{\mathrm{aB}}$ & $12.75 \pm 1.40^{\mathrm{abBC}}$ & $16.98 \pm 1.57^{\mathrm{aA}}$ \\
\hline 30 & $10.60 \pm 3.27^{\mathrm{bcc}}$ & $16.05 \pm 2.30^{\mathrm{aA}}$ & $12.04 \pm 1.33^{\mathrm{aBC}}$ & $14.28 \pm 2.23^{\mathrm{aAB}}$ & $12.12 \pm 1.22^{\mathrm{bBC}}$ \\
\hline 60 & $12.56 \pm 1.04^{\mathrm{abA}}$ & $13.44 \pm 1.87^{\mathrm{abA}}$ & $12.32 \pm 0.86^{\mathrm{aA}}$ & $11.56 \pm 1.62^{\mathrm{bcA}}$ & $12.34 \pm 0.97^{\mathrm{bA}}$ \\
\hline 90 & $14.29 \pm 1.05^{\mathrm{aA}}$ & $11.28 \pm 3.07^{\mathrm{bcB}}$ & $11.01 \pm 0.87^{\mathrm{aB}}$ & $10.36 \pm 1.56^{\mathrm{CB}}$ & $12.46 \pm 2.00^{\mathrm{bAB}}$ \\
\hline \multicolumn{6}{|c|}{$b^{*}$} \\
\hline 0 & $6.09 \pm 4.23^{\mathrm{aB}}$ & $4.58 \pm 0.65^{\mathrm{bB}}$ & $8.07 \pm 3.06^{\mathrm{abAB}}$ & $8.31 \pm 4.63^{\text {аАВ }}$ & $11.26 \pm 1.51^{\mathrm{aA}}$ \\
\hline 30 & $8.89 \pm 0.89^{a A}$ & $9.50 \pm 2.89^{a A}$ & $8.89 \pm 2.36^{a A}$ & $8.83 \pm 2.62^{\mathrm{aA}}$ & $7.71 \pm 1.19^{\mathrm{bA}}$ \\
\hline 60 & $7.55 \pm 0.85^{\mathrm{aA}}$ & $8.33 \pm 3.01^{\mathrm{aA}}$ & $6.69 \pm 0.51^{\mathrm{abA}}$ & $8.63 \pm 7.92^{\mathrm{aA}}$ & $8.04 \pm 1.44^{\mathrm{bA}}$ \\
\hline 90 & $8.93 \pm 0.76^{a A}$ & $6.52 \pm 1.78^{\mathrm{abBC}}$ & $6.13 \pm 0.47^{b c}$ & $7.63 \pm 0.33^{\mathrm{aABC}}$ & $8.16 \pm 1.65^{\mathrm{bAB}}$ \\
\hline \multicolumn{6}{|c|}{$L^{*}$} \\
\hline 0 & $27.99 \pm 3.93^{a A}$ & $23.15 \pm 2.29 \mathrm{abA \textrm {B }}$ & $26.04 \pm 3.42^{\mathrm{aA}}$ & $28.83 \pm 8.33^{\mathrm{aA}}$ & $31.37 \pm 3.23^{\mathrm{aA}}$ \\
\hline 30 & $33.55 \pm 10.68^{a A}$ & $29.29 \pm 2.58^{\mathrm{aA}}$ & $28.72 \pm 2.27^{\mathrm{aA}}$ & $28.55 \pm 4.78^{\mathrm{aA}}$ & $28.93 \pm 5.36^{\mathrm{aA}}$ \\
\hline 60 & $28.62 \pm 3.44^{\mathrm{aA}}$ & $28.04 \pm 7.03^{\mathrm{aA}}$ & $27.00 \pm 1.80^{\mathrm{aA}}$ & $29.79 \pm 1.15^{\mathrm{aA}}$ & $29.20 \pm 3.70^{\mathrm{aA}}$ \\
\hline 90 & $29.04 \pm 2.95^{\mathrm{aA}}$ & $26.58 \pm 3.02^{\mathrm{aA}}$ & $25.68 \pm 1.32^{\mathrm{aA}}$ & $28.27 \pm 5.37^{a A}$ & $29.40 \pm 3.76^{\mathrm{Aa}}$ \\
\hline
\end{tabular}

Standard - ( $\mathrm{NaCl} 100 \%+7$ days salting); $\mathrm{T} 1-(\mathrm{NaCl} 65 \%+4$ days salting); $\mathrm{T} 2-(\mathrm{NaCl} 65 \%+5$ days salting); $\mathrm{T} 3-(65 \% \mathrm{NaCl}+35 \% \mathrm{KCl}+4$ days salting); $\mathrm{T} 4$ $-(65 \% \mathrm{NaCl}+35 \% \mathrm{KCl}+5$ days salting). Mean rates $(\mathrm{n}=3)$ followed by their standard deviation. Means followed by the same small letter in the same column do not statistically differ at $5 \%$ probability by Tukey test $(p<0.05)$. Means followed by the same capital letter in the same line do not statistically differ at $5 \%$ probability by Tukey test $(p<0.05)$.

$\mathrm{NaCl}$ had the lowest moisture content (47\%), compared with the treatments containing $\mathrm{KCl}$ (Aliño et al., 2009). These results corroborate those reported by other authors who observed higher moisture content in salty bacon samples with $30 \% \mathrm{NaCl}$ and $70 \% \mathrm{KCl}$ compared to samples salted with $100 \% \mathrm{NaCl}$ (Stanley et al., 2017).

On the other hand, in an evaluation of the partial substitution of $\mathrm{NaCl}$ by a commercial additive composed of $\mathrm{KCl}$ they observed that the control treatment with $100 \%$ of $\mathrm{NaCl}$ had a higher moisture content $(70.64 \%)$, compared to the treatment containing $35 \%$ of $\mathrm{KCl}(67.32 \%)$ in frozen sliced meat ready for consumption (Aliño et al., 2009).

In this study it was not possible to affirm the relationship between salt content and moisture percentage of the product. The pieces of the shoulder used to carry out this experiment vary in percentage of fat, and for each analysis different pieces were used. The diverse level of fat leads to the unevenness of the pieces and interferes in the results, because the higher the fat content the lower the moisture content. This factor also affects the smoking and maturation processes (Sabadini et al., 2001).

The lipid content influences product quality, as it imparts succulence to the meat, as well as acting on the taste and its conservation (Rosenvold and Andersen, 2003). There was great variation in lipid contents among the samples. Factors such as animal weight or carcass weight have a strong influence especially on intramuscular fat level and this is reflected directly in the meat's technological characteristics. Pork is a meat rich in lipids, cholesterol, saturated and unsaturated fatty acids. Genetics, sex, age, and dietary management influence fatty acid concentrations, ranging from 8 to $55 \%$ (Khanal et al., 2019).

The results of lipid concentration of the ready-toeat sliced frozen roast beef, the control treatment $100 \%$ $\mathrm{NaCl}), \mathrm{T} 1$ treatment $(35 \%$ reduction $\mathrm{NaCl})$ and $\mathrm{T} 2(70 \%$ reduction $\mathrm{NaCl}$ ) presented lipid levels of $2.44 ; 2.47$ and $1.87 \%$, respectively (Richardson and Jones, 1987).

Brazilian legislation has established that the protein content for coppa should be at least $20 \%$ and in this study all the samples at all storage times presented adequate levels of protein (Table 3).

The conservation of meat products can also be obtained through the use of nitrite and nitrate, two substances which also play an antioxidant role, and act to inhibit microbial development, in addition to fixing the reddish pink color in cured products (Souza et al., 2013).

The high levels of nitrite in the body can lead to the production of methemoglobin, which makes it more difficult to transport oxygen through the body. Whatsmore, this can form nitrosamines, carcinogenic substances from the action of nitrates and nitrites on secondary amines (Song et al., 2015).

In this study, the nitrate levels were significantly different between all treatments and between themselves at all storage times $(p<0.05)$. This difference can be explained by the process, since the salting and re-salting are carried out manually. For nitrite levels there was also significant variation $(p<0.05)$ between the pieces of all treatments for all storage time periods. Although there were significant differences between the treatments, the residual percentage of nitrite measured varied from 0.75 to $8.81 \mathrm{mg} \mathrm{kg}^{-1}$, which is in accordance with Brazilian legislation. The limit established for the use of nitrates and nitrites cannot exceed 300 and 150 parts per million, respectively.

As shown in Table 4, there was no significant difference $(p>0.05)$ in $\mathrm{pH}$ values in treatments at 30 and 90 storage days. The small variations are due to the raw material, which differs from one animal to another in the slaughter process, for each piece of shoulder cuts used. This variation in $\mathrm{pH}$ between samples is expected in biological studies. Although significant differences $(p<$ 
$0.05)$ in $\mathrm{pH}$ values between treatments and storage times were observed, this variation theoretically does not affect the quality of the product as regards this parameter. In a study carried out on piacentine sliced coppa $\mathrm{pH}$ values between 5.76 and 5.98 were observed inside the product and on the surface of the piece, respectively, during the 6-month storage period (Busconi et al., 2014).

Lower $\mathrm{pH}$ values were found in cured ham (Delgado-Pando et al., 2018). The mean $\mathrm{pH}$ value was 5.83 obtained through the use of a mixture of salts, while in formulations with higher $\mathrm{NaCl}$ content the values were between 5.96 and 6.08. Higher $\mathrm{pH}$ values may be related to basic compounds resulting from proteolysis due to the action of proteinases. The mold presence on parts of the coppas can lead to ammonia production from amino acids and contribute to an increase in $\mathrm{pH}$ (Domínguez et al., 2016) whereas in a study on salami it was verified that the $\mathrm{NaCl}$ substitution by a mixture of $\mathrm{KCl}$ and $\mathrm{CaCl}_{2}$ did not cause any significant difference $(p>0.05)$ in the $\mathrm{pH}$ (Almeida et al., 2016). In certain cases, when $\mathrm{pH}$ changes occur, e.g. the decrease in $\mathrm{pH}$ values with the addition of $\mathrm{CaCl}_{2}$, it is related to two atoms of $\mathrm{Cl}-$ (anions) in its composition, leading to lower $\mathrm{pH}$ values when compared to monovalent salts $\mathrm{NaCl}$ and $\mathrm{KCl}$ (Fieira, et al., 2018; Vidal et al., 2019). Additionally, the vacuum packaged storage of salted meat can cause lactic fermentation and a gradual decrease in $\mathrm{pH}$ values (Santos et al., 2015).

The water activity results presented in Table 4 corroborate the limits specified on the legislation (0.90). Thus, the results below 0.93 served as a barrier to microorganism development (Terra et al., 2013). Therefore, processed meats with water activity between 0.97 and 0.98 have a reduced shelf life. These values correspond to the optimum development range of deteriorating bacteria such as Pseudomonas fluorescens, especially in products having a low sodium chloride content (Richardson and Jones, 1987). In our study, the 60-day storage period, in all treatments, did not show any significant difference $(p>0.05)$. The observed changes may be related to several factors such as the initial water content of the raw shoulder cuts, or the position of each piece in the smoker during both the smoking and the maturation room processes.

The initial water activity in the pork shoulder cut is on average 0.97. However, during the salting process, water loss and solute gain decrease through the product's structural changes with shrinkage of the matrix, and rupture of the membranes of the surface cells consequently leading to a compression of the surface layers and an increased resistance to mass transfer (Sabadini et al., 2001).

The $\mathrm{NaCl}$ reduction and its substitution by $\mathrm{KCl}$ and $\mathrm{CaCl}_{2}$ in salami showed that at the end of maturation the lowest Aw value was observed in the treatment carrying the highest $\mathrm{NaCl}$ content (Almeida et al., 2016). This fact corroborates the values found in this study. The standard treatment presented the lowest Aw value. In meat, salt in low concentrations increase water holding capacity.
On the other hand, high salt concentrations precipitate meat proteins, leading to lower water holding capacity (Richardson and Jones, 1987).

\section{Microbiological Analysis}

Microbiological results of thermotolerant coliforms, coagulase-positive Staphylococcus, Salmonella sp. and Listeria monocytogenes observed the limits established for the microbiological sanitary Brazilian standards for food (ANVISA, 2001). Factors such as good manufacturing practices, hygienic habits and adequate disinfection of equipment and utensils are preponderant in order to ensure the microbiological quality and harmlessness of meat products. In addition, the Aw characteristic of this product made bacterial multiplication difficult, increasing food safety and shelf life.

\section{Color Analysis}

In addition to microbiological food safety, the physical characteristics of meat products are important to consumers. Color is a physical attribute that is essential to the attractiveness of a cured product.

The $a^{*}$ values varied in all treatments, except for treatment $\mathrm{T} 2$ which remained stable during the 90-day storage period. In this research study, a reduction in parameter $\mathrm{a}^{*}$ was observed for the treatments T2, T3 and $\mathrm{T} 4$ against an increase in this parameter in the standard treatment. The literature discusses the interference of $\mathrm{NaCl}$ with the heme pigment content: the higher the $\mathrm{NaCl}$ content, the lower the heme pigment content, and consequently the lower the red intensity (Santos et al., 2017).

The $b^{*}$ is one of the color parameters that may be related to lipid oxidation in meat products. In a study carried out on salami, the substitution of $\mathrm{NaCl}$ interfered with the intensity of the yellow color. An increase in $b^{*}$ intensity after 90-day storage was verified by Busconi et al. (2014). Therefore, for $b^{*}$, in this study no significant difference $(p<0.05)$ between the standard treatment and T3 during the storage period was found (Table 5). For $\mathrm{T} 2$ and $\mathrm{T} 4$ reductions in $\mathrm{b}^{*}$ were observed when both treatments were exposed to salt for 5 days.

The parameter $\mathrm{L}^{*}$ (luminosity) did not present significant differences between treatments. Similar data were found in salami with salting consisting of $50 \%$ of $\mathrm{NaCl}$ and $50 \%$ of $\mathrm{KCl}$ (García-Macías et al., 1996) and in cured loin, with $\mathrm{NaCl}$ substitutions up to $70 \%$ (Souza et al., 2013).

\section{Sensory Analysis}

Sensory analysis was carried out after 30 days of maturation of the product. For the results analysis Principal Component Analysis (PCA) and Hierarchical Cluster Analysis (HCA) methods were used. PCA enables the identification of data responsible for the largest variation between results without significant loss of information, as well as allowing for the grouping of similar characteristics. 
In the main components analysis (Figure 1) the conclusion of the physicochemical evaluation with the product considered the saltiest was the standard treatment. Furthermore, the standard treatment presented lower intensity for parameters $\mathrm{a}^{*}$ and $\mathrm{b}^{*}$ as at 0 -day storage.

In $\mathrm{HCA}$, the treatments that were most similar with the shortest distance between them were thus the most homogeneous. As shown in Figure 2, treatments T1 and $\mathrm{T} 2$ had greater similarity in the attributes of color and odor. On the other hand, they scored in salty and bitter flavors, which were grouped with the attributes of an ideal profile by the tasters.

These results demonstrate that the reduction of exposure time of the product to salt reduced the intensity of salty taste. However, the $\mathrm{KCl}$ concentration used in coppa left the product with a bitter taste, which was perceived by the tasters, especially in T4. Therefore, treatments 1 and 2 can be used as the basis for the development of a healthier formulation and were closest to the ideal profile desired by the consumer.

In dry-cured bacon with $\mathrm{NaCl}$ substituted by $\mathrm{KCl}$ no significant difference $(p>0.05)$ was observed between treatments in terms of color as a sensorial parameter. The treatment added with $\mathrm{KCl}$ showed a reduction in salty taste; however, there was the perception of a bitter taste. Treatment with $60 \% \mathrm{KCl}$ was not sensorially accepted, levels up to $40 \%$ proving to be the most acceptable (Li et al., 2016). Small KCl additions (0.64 \%) did not result either in a significant increase of bitterness or any other kind of sensory alterations in fuet salami (Mora-Gallego., 2016). Studies with partial replacement of $\mathrm{NaCl}$ by $\mathrm{KCl}$ or $\mathrm{CaCl} 2$ and the addition of different flavor enhancers increased sensory acceptance and decreased the rancid aroma, salty flavor and residual flavor of salty meat (Vidal et al., 2020a; Vidal et al., 2020b).

\section{Conclusion}

Sodium reduction in industrialized pork coppa did not cause significant alterations to the microbiological and physicochemical parameters. The salting and resalting time reduction and partial $\mathrm{NaCl}$ replacement by $\mathrm{KCl}$ was efficient in obtaining a reduction from 2,000 mg to $1,600 \mathrm{mg}$ of sodium. Sensory evaluation demonstrated that reduction of the re-salting time was efficient in obtaining a product that complies with consumer expectations. Thus, treatments $\mathrm{T} 1$ and $\mathrm{T} 3$ presented a less salty taste in a way that provided the best results based on the ideal profile constructed by the tasters whereby it becomes possible to develop new formulations in order to obtain a product with greater sensorial acceptance and low sodium content.

\section{Authors' Contributions}

Conceptualization: Di Domenico, J.; Lucchetta, L. Data acquisition: Di Domenico, J. Data analysis: Di Domenico, J.; Prado, N.V.; Weber, C.I. Design of methodology: Di Domenico, J.; Prado, N.V.; Weber, C.I.; Machado-Lunckes, A.; Lucchetta, L. Writing and editing: Di Domenico, J.; Lucchetta, L., Weber, C.I.; Machado-Lunckes, A.

\section{Acknowledgments}

To the Brazilian National Council for Scientific and Technological Development (CNPq), Araucária Foundation, Federal Technological University of Paraná.

\section{References}

Agência Nacional de Vigilância Sanitária [ANVISA]. 2001. Collegiate Board Resolution = Resolução da Diretoria Colegiada - RDC n ${ }^{\circ} 12$, de 2 de janeiro de 2001. ANVISA, Brasília, DF, Brazil (in Portuguese).

Aliño, M.; Grau, R.; Toldrá, F.; Blesa, E.; Pagán, M.J.; Barat, J.M. 2009. Influence of sodium replacement on physicochemical properties of dry-cured loin. Meat Science 83: 423-430. https:// doi.org/10.1016/j.meatsci.2009.06.022

Almeida, M.A.D.; Villanueva, N.D.M.; Pinto, J.S.D.S.; Saldaña, E.; Contreras-Castillo, C.J. 2016. Sensory and physicochemical characteristics of low sodium salami. Scientia Agricola 73: 347355. https://doi.org/10.1590/0103-9016-2015-0096

American Public Health Association [APHA]. 1992. Compendium of Methods for Microbiological Examination of Food. APHA, Washington, DC, USA.

Andrade, J.C.; Nalério, E.S.; Giongo, C.; Barcellos, M.D.; Ares, G.; Deliza, R. 2018. Consumer sensory and hedonic perception of sheep meat coppa under blind and informed conditions. Meat Science 137: 201-210. https://doi.org/10.1016/j. meatsci.2017.11.026

Association of Official Analytical Chemists [AOAC]. 2005. Official Methods of Analysis. 18ed. Gaithersburg, MD, USA.

Busconi, M.; Zacconi, C.; Scolari, G. 2014. Bacterial ecology of PDO Coppa and Pancetta Piacentina at the end of ripening and after MAP storage of sliced product. International Journal of Food Microbiology 172: 13-20. https://doi.org/10.1016/j. ijfoodmicro.2013.11.023

Delgado-Pando, G.; Fischer, E.; Allen, P.; Kerry, J.P.; O'Sullivan, M.G.; Hamill, R.M. 2018. Salt content and minimum acceptable levels in whole-muscle cured meat products. Meat Science 139: 179-186. https://doi.org/10.1016/j.meatsci.2018.01.025

Domínguez, R.; Munekata, P.E.; Cittadini, A.; Lorenzo, J.M. 2016. Effect of the partial $\mathrm{NaCl}$ substitution by other chloride salts on the volatile profile during the ripening of dry-cured lacón. Grasas y Aceites 67: 128. https://doi.org/10.3989/ gya.0505152

Doyle, M.E.; Glass, K.A. 2010. Sodium reduction and its effect on food safety, food quality, and human health. Comprehensive Reviews in Food Science and Food Safety 9: 44-56. https://doi. org/10.1111/j.1541-4337.2009.00096.x

Fieira, C.; Marchi, J.F.; Marafão, D.; Alfaro, A.D.T. 2018. The impact of the partial replacement of sodium chloride in the development of starter cultures during Italian salami production. Brazilian Journal of Food Technology 21: e2015036. https://doi.org/10.1590/1981-6723.03615 
Inguglia, E.S.; Zhang, Z.; Tiwari, B.K.; Kerry, J.P.; Burgess, C.M. 2017. Salt reduction strategies in processed meat products: a review. Trends in Food Science \& Technology 59: 70-78. https:// doi.org/10.1016/j.tifs.2016.10.016

Khanal, P.; Maltecca, C.; Schwab, C.; Gray, K.; Tiezzi, F. 2019. Genetic parameters of meat quality, carcass composition, and growth traits in commercial swine, Journal of Animal Science 97: 3669-3683. https://doi.org/10.1093/jas/skz247

Koniecko, E.S. Handbook for Meat Chemists. 1985. Avery Publishing, New York, NY, USA.

Li, F.; Zhuang, H.; Qiao, W.; Zhang, J.; Wang, Y. 2016. Effect of partial substitution of $\mathrm{NaCl}$ by $\mathrm{KCl}$ on physicochemical properties, biogenic amines and $\mathrm{N}$-nitrosamines during ripening and storage of dry-cured bacon. Journal of Food Science and Technology 53: 3795-3805. https://doi.org/10.1007/ s13197-016-2366-x

Ma, H.J.; Ledward, D.A.; Zamri, A.I.; Frazier, R.A.; Zhou, G.H. 2007. Effects of high pressure/thermal treatment on lipid oxidation in beef and chicken muscle. Food Chemistry 104: 1575-1579. https://doi.org/10.1016/j.foodchem.2007.03.006

Ministério da Agricultura, Pecuária e Abastecimento [MAPA]. 2000. Normative Instruction $=$ Instrução Normativa $\mathrm{N}^{\circ}$ 22, de 31 de julho de 2000. Diário Oficial da União de 3 de agosto de 2000, Seção 1, p. 15. MAPA, Brasília, DF, Brazil (in Portuguese).

Mora-Gallego, H.; Guàrdia, M.D.; Serra, X.; Gou, P.; Arnau, J. 2016. Sensory characterisation and consumer acceptability of potassium chloride and sunflower oil addition in smallcaliber non-acid fermented sausages with a reduced content of sodium chloride and fat. Meat Science 112: 9-15. https://doi. org/10.1016/j.meatsci.2015.10.008

Nachtigall, F.M.; Vidal, V.A.S.; Pyarasani, R.D.; Domínguez, R.; Lorenzo, J.M.; Pollonio, M.A.R.; Santos, L.S. 2019. Substitution effects of $\mathrm{NaCl}$ by $\mathrm{KCl}$ and $\mathrm{CaCl} 2$ on lipolysis of salted meat. Foods 8: 595. https://doi.org/10.3390/foods8120595

Parpia, A.S.; Goldstein, M.B.; Arcand, J.; Cho, F.; L'Abbé, M.R.; Darling, P.B. 2018. Sodium-reduced meat and poultry products contain a significant amount of potassium from food additives. Journal of the Academy of Nutrition and Dietetics 118: 878885. https://doi.org/10.1016/j.jand.2017.10.025

Richardson, R.I.; Jones, J.M. 1987. The effects of salt concentration and $\mathrm{pH}$ upon water-binding, water-holding and protein extractability of turkey meat. International Journal of Food Science \& Technology 22: 683-692. https://doi. org/10.1111/j.1365-2621.1987.tb00537.x

Rosenvold, K.; Andersen, H.J. 2003. Factors of significance for pork quality: a review. Meat Science 64: 219-237. https://doi. org/10.1016/S0309-1740(02)00186-9

Sabadini, E.; Hubinger, M.D.; Sobral, P.D.A.; Carvalho, J. 2001. Change of water activity and meat colour in the elaboration process of dehydrated salted meat. Food Science and Technology 21: 14-19. https://doi.org/10.1590/S0101-20612001000100005 (in Portuguese, with abstract in English)

Santos, B.A. ; Campagnol, P.C.B. ; Fagundes, M.B.; Wagner, R.; Pollonio, M.A.R. 2017. Adding blends of $\mathrm{NaCl}, \mathrm{KCl}$, and $\mathrm{CaCl} 2$ to low-sodium dry fermented sausages: effects on lipid oxidation on curing process and shelf life. Journal of Food Quality 2017: Article ID 7085798. https://doi.org/10.1155/2017/7085798
Santos, B.A.; Campagnol, P.C.B.; Cruz, A.G.; Morgano, M.A.; Wagner, R.; Pollonio, M.A.R. 2015. Is there a potential consumer market for low-sodium fermented sausages?. Journal of Food Science 80: S1093-S1099. https://doi.org/10.1111/17503841.12847

Seganfredo, D.; Rodrigues, S.; Kalschne, D.L.; Sarmento, C.M.P.; Canan, C. 2016. Partial substitution of sodium chloride in Toscana sausages and the effect on product characteristics. Semina: Ciências Agrárias 37: 1285-1294. http://dx.doi. org/10.5433/1679-0359.2016v37n3p1285

Song, P.; Wu, L.; Guan, W. 2015. Dietary Nitrates, Nitrites, and Nitrosamines Intake and the Risk of Gastric Cancer: A MetaAnalysis. Nutrients 7: 9872-9895. https://doi.org/10.3390/ nu7125505

Souza, M.A.; Visentainer, J.V. Carvalho, R.H.; Garcia, F.; Ida, E.I.; Shimokomaki, M. 2013. Lipid and protein oxidation in charqui meat and jerked beef. Brazilian Archives of Biology and Technology 56: 107-112. https://doi.org/10.1590/S151689132013000100014

Stanley, R.E.; Bower, C.G.; Sullivan, G.A. 2017. Influence of sodium chloride reduction and replacement with potassium chloride based salts on the sensory and physico-chemical characteristics of pork sausage patties. Meat Science 133: 36-42.

Terra, N.N.; Cichoski, A.J.; Freitas, R.J.S.D. 2008. Microbiological and physical chemical aspects in the internal parts pig palette cured, matured and fermented during processing and storage. Ciência Rural 38: 1118-1124. https://doi.org/10.1590/S010384782008000400033 (in Portuguese, with abstract in English).

Varela, P.; Ares, G. 2014. Novel Techniques in Sensory Characterization and Consumer Profiling. CRC Press, Boca Raton, FL, USA.

Vidal, V.A.; Biachi, J.P.; Paglarini, C.S.; Pinton, M.B.; Campagnol, P.C.; Esmerino, E.A.; Pollonio, M.A. 2019. Reducing 50 $\%$ sodium chloride in healthier jerked beef: an efficient design to ensure suitable stability, technological and sensory properties. Meat Science 152: 49-57. https://doi.org/10.1016/j. meatsci.2019.02.005.

Vidal, V.A.; Paglarini, C.S.; Freitas, M.Q.; Coimbra, L.O.; Esmerino, E.A.; Pollonio, M. A.; Cruz, A.G. (2020b). Q Methodology: an interesting strategy for concept profile and sensory description of low sodium salted meat. Meat Science 161: 108000. https:// doi.org/10.1016/j.meatsci.2019.108000

Vidal, V.A.; Santana, J.B.; Paglarini, C.S.; Silva, M.A.; Freitas, M.Q.; Esmerino, E.A.; Pollonio, M.A. 2020a. Adding lysine and yeast extract improves sensory properties of low sodium salted meat. Meat Science 159: 107911. https://doi.org/10.1016/j. meatsci.2019.107911

Worch, T.; Punter, P.H. 2015. Ideal profiling as a sensory profiling technique. p. 307-332. In: Delarue, J.; Lawlor, J.B.; Rogeaux, M., eds. Rapid sensory profiling techniques and related methods. Elsevier, Amsterdam, Holland.

World Health Organization [WHO]. 2016. Salt reduction. WHO, Geneve, Switzerland.

Wu, H.; Zhuang, H.; Zhang, Y.; Tang, J.; Yu, X.; Long, M.; Zhang, J. 2015. Influence of partial replacement of $\mathrm{NaCl}$ with $\mathrm{KCl}$ on profiles of volatile compounds in dry-cured bacon during processing. Food Chemistry 172: 391-399. https://doi. org/10.1016/j.foodchem.2014.09.088 